\title{
TANGGUNG JAWAB PERUSAHAAN ANGKUTAN UDARA TERHADAP KETERLAMBATAN PENERBANGAN (STUDI PADA PT. LION MENTARI AIRLINES)
}

\author{
Desak Putu Dian Sucitawati, Fakultas Hukum Universitas Udayana, e-mail: \\ dianbe_desak@yahoo.com \\ Ida Bagus Putra Atmadja, Fakultas Hukum Universitas Udayana, e-mail: \\ putra_atmadja@unud.ac.id
}

doi: https://doi.org/10.24843/KS.2020.v08.i10.p05

\begin{abstract}
ABSTRAK
Tujuan dari penulisan artikel dalam jurnal ini untuk mengkaji mengenai hubungan hukum antara perusahaan penerbangan dengan penumpang, serta untuk mengetahui tanggungjawab perusahaan penerbangan terhadap penumpang apabila terjadi penundaan penerbangan. Tulisan ini menggunakan metode penelitian yuridis empiris dengan dengan sifat penelitian deskriptif kualitatif. Hasil studi menunjukkan bahwa hubungan hukum antara Perusahaan Angkutan Penerbangan dengan penumpang adalah hubungan hukum yang sifatnya perjanjian berkala yaitu perjanjian dengan syarat dilakukan hanya untuk waktu tertentu dan perbuatan tertentu. Sesuai dengan Peraturan Menteri Nomor 77 tahun 2011 tentang Tanggung Jawab Pengangkut Angkutan Udara di Pasal 10, yaitu keterlambatan lebih dari 4 (empat) jam akan mengakibatkan pembayaran kompensasi sebesarRp.300.000,00 (tiga ratus ribu Rupiah) untuk masing-masing penumpang.
\end{abstract}

Kata kunci : Tanggungjawab, Perusahaan Penerbangan, Keterlambatan Penerbangan

\begin{abstract}
The purpose of articles in this journal is to examine the legal relationship between airline companies and passengers, as well as to find out the responsibility of airlines to passengers in the event of flight delays. This paper uses an empirical juridical research method with qualitative descriptive research characteristics. The results of the study show that the legal relationship between the Aviation Transportation Company and passengers is a legal relationship which is a periodic agreement, namely an agreement with the condition that it is carried out only for a certain time and for certain actions. In accordance with Ministerial Regulation Number 77 of 2011 concerning the Responsibility of Air Transport Carriers in Article 10, namely a delay of more than 4 (four) hours will result in the payment of compensation of Rp. 300,000.00 (three hundred thousand Rupiah) for each passenger.
\end{abstract}

Keywords: Responsibility, Airline, Flight Delay

\section{Pendahuluan}

\subsection{Latar Belakang}

Penerbangan merupakan salah satu transportrasi yang sudah banyak digunakan oleh masyarakat. Hal ini dapat terjadi dikarenakan kebutuhan masyarakat akan transportasi untuk jarak jauh sudah cukup tinggi terlihat dari jumlah penumpang setiap penerbangan dalam maupun luar negeri. Selain itu harga dari moda transportasi 
penerbangan sudah terjangkau oleh masyarakat di Indonesia tidak seperti beberapa tahun silam. Menjamurnya perusahaan penerbangan dalam kurun waktu 10 tahun terakhir di satu sisi memberikan implikasi positif bagi masyarakat pengguna jasa penerbangan, yaitu banyak pilihan atas operator penerbangan dengan berbagai ragam pelayanannya.

Di samping itu, banyaknya perusahaan penerbangan telah menciptakan iklim yang kompetitif antara satu perusahaan penerbangan dengan perusahaan penerbangan lainya yang pada ujungnya melahirkan tiket murah yang paling menarik masyarakat secara antusias. Namun, kompetisi ini pada sisi lain juga menimbulkan kekhawatiran bahwa harga tiket murah akan berdampak pada kualitas layanan, khususnya layanan atas perawatan pesawat. Tarif yang murah tersebut sering menurunkan kualitas pelayanan (service), bahkan yang lebih mengkhawatirkan lagi adalah akan menyebabkan berkurangnya kualitas pemeliharaan (maintenance) pesawat sehingga rawan terhadap keselamatan penerbangan dan akan berdampak kurang baik terhadap keamanan, kenyamanan dan perlindungan konsumen. ${ }^{1}$ Kekhawatiran tersebut muncul akibatnya sering terjadinya kecelakaan pesawat terbang. ${ }^{2}$

Dalam jasa penerbangan kita ketahui sering sekali terjadi penundaan waktu yang cukup menguras waktu dan merugikan penumpang pesawat tersebut. Dalam jasa penerbangan terdapat keluhan-keluhan lain dari para penumpang selain adanya penundaan waktu atau delay, yaitu persoalan barang bagasi yang hilang, dan keluhankeluhan lainnya. Pada dasarnya dalam kegiatan pengangkutan udara niaga terdapat dua pihak, yaitu pengangkut dalam hal ini adalah perusahaan atau maskapai penerbangan dan pihak pengguna jasa atau konsumen. Para pihak tersebut terikat oleh suatu perjanjian, yaitu perjanjian pengangkutan. Sebagaimana layaknya suatu perjanjian yang merupakan manisfestasi dari hubungan hukum yang bersifat keperdataan maka di dalamnya terkandung hak dan kewajiban yang harus dilaksanakan dan dipenuhi, yang biasa dikenal dengan istilah "prestasi".

Dalam hukum pengangkutan, kewajiban pengangkut antara lain mengangkut penumpang dan/atau barang dengan aman, utuh dan selamat sampai di tempat tujuan, memberikan pelayanan yang baik, mengganti kerugian penumpang dalam hal adanya kerugian yang menimpa penumpang, memberangkatkan penumpang sesuai dengan jadwal yang telah ditetapkan dan lain-lain. Kewajiban penumpang adalah membayar ongkos pengangkutan yang besarnya telah ditentukan, menjaga barangbarang yang berada dibawah pengawasannya, melaporkan jenis-jenis barang yang dibawa terutama barang-barang yang berkategori berbahaya, mentaati ketentuanketentuan yang ditetapkan pengangkut yang berkenaan dengan pengangkutan.

Hak dan kewajiban para pihak tersebut biasanya dituangkan dalam suatu dokumen perjanjian pengangkutan. Secara teoritis, perjanjian pengangkutan merupakan suatu perikatan dimana satu pihak menyanggupi untuk dengan aman membawa orang atau barang dari suatu tempat ke tempat lain sedangkan pihak

1 Wiradipradja, E. Saefullah. "Tanggung Jawab Perusahaan Penerbangan Terhadap Penumpang Menurut Hukum Udara Indonesia." Jurnal Hukum Bisnis 25, no. 1 (2006), 5.

2 Prajogo, Abimanyu Faiz, and H. K. Martono. "TANGGUNG JAWAB PENGANGKUT TERHADAP PENUMPANG YANG TIDAK TERDAFTAR DALAM MANIFES (STUDI KASUS JATUHNYA PESAWAT LION AIR JT 610 DI KARAWANG)." Jurnal Hukum Adigama 2, no. 2 (2019). 1-19. 
lainnya, menyanggupi untuk membayar ongkosnya. ${ }^{3}$ Penundaan penerbangan tersebut tentu akan menimbulkan kerugian bagi penumpang sebagai pihak konsumen, sehingga sudah sewajarnya bagi maskapai penerbangan untuk memberikan ganti rugi ataupun bertanggung jawab atas kerugian yang diterima oleh penumpang. ${ }^{4}$ Akan tetapi kepastian hukum perlindungan konsumen belum juga diselenggarakan oleh maskapai penerbangan bahkan sering kita dengar hal-hal serta permasalahan konsumen yang dirugikan masih saja tetap ada.

\subsection{Rumusan masalah}

Berdasarkan latar belakang yang telah diuraikan, beberapa permasalahan yang dikaji dalam tulisan ini sebagai berikut:

1.Bagaimanakah hubungan hukum antara perusahaan penerbangan dengan penumpang?

2.Bagaimanakah tanggung jawab perusahaan penerbangan terhadap penumpang dalam hal terjadinya penundaan penerbangan?

\subsection{Tujuan Penulisan}

Tulisan ini bertujuan untuk mengkaji mengenai hubungan hukum antara perusahaan penerbangan dengan penumpang, serta untuk mengetahui tanggungjawab perusahaan penerbangan terhadap penumpang apabila terjadi penundaan penerbangan.

\section{Metode Penelitian}

Tulisan ini menggunakan metode penelitian yuridis empiris, yaitu penelitian hukum yang didasarkan atas peraturan perundang-undangan dan teori yang ada kaitannya dengan fakta yang ada di lapangan. Pendekatan yuridis empiris berdasarkan atas peraturan perundang-undangan yang berlaku yang ada kaitannya dengan masalah ini, sedangkan pendekatan empiris yaitu dengan cara melihat peraturan-peraturan yang mengaturnya dan kemudian melihat penerapannya di lapangan. ${ }^{5}$ Sumber data yang digunakan dalam penelitian ini adalah data primer dan data sekunder. Data yang diperoleh dalam penelitian ini didapatkan dengan teknik wawancara dan studi dokumen. Adapun data primer terdiri dari hasil wawancara dengan bagian Operasional dan Tiketing PT. Lion Mentari Airlines (Cabang Bandara Ngurah Rai) sedangkan data sekunder yang digunakan terdiri dari bahan hukum primer yaitu berupa perundang-undangan yang terkait dengan permasalahan yang diangkat, bahan hukum sekunder berupa buku-buku dan jurnal yanng berkaitan dengan Perlindungan konsuman dalam hukum pengangkutan dan bahan hukum sekunder berupa internet.

pengumpulan data menggunakan teknik wawancara.Informan dalam penelitian ini adalah PT. Angkasa Pura I, PT. Garuda Indonesia, dan Annika Linden Center.

3 MAIZANI, SITI ADLIAH, Annalisa Yahanan, and Arfianna Novera. "TANGGUNG JAWAB PT. LION AIR ATAS KEHILANGAN BAGASI TERCATAT PENUMPANG (Studi Putusan Mahkamah Agung Nomor 2985 K/Pdt/2013)." PhD diss., Sriwijaya University, 2018.

4 Amalia, Laili Rizki. "Perlindungan Hukum Konsumen Jasa Akibat Pembatalan Keberangkatan Jamaah Umroh Berdasarkan Undang-undang Perlindungan Konsumen." PhD diss., UNIVERSITAS 17 AGUSTUS 1945, 2018.

5 Marzuki, Peter Mahmud, Penelitian Hukum, (Jakarta, Prenada Media Group, 2008), 93. 


\section{Hasil dan Pembahasan}

\subsection{Hubungan Hukum Antara Perusahaan Penerbangan dengan Penumpang}

Dalam perjanjian pengangkutan terdapat hak dan kewajiban para pihak yang harus dilaksanakan dengan baik. Hak dan kewajiban timbul karena adanya hubungan hukum diantara para pihak. Apabila penumpang tidak melaksanakan kewajibannya itu, maka sebagai konsekuensinya pengakut udara berhak untuk membatalkan perjanjian angkutan udara itu. ${ }^{6}$ Disamping itu juga apabila penumpang yang melalaikan kewajibannya itu kemudian menimbulkan kerugian sebagai akibat perbuatannya itu, maka sebagai penumpang harus bertanggung jawab atas kerugian tersebut.

Secara umum kewajiban pengangkut adalah menyelenggarakan pengangkutan barang atau penumpang beserta bagasinya dan menjaganya dengan sebaik-baiknya hingga sampai di tempat tujuan. Menurut undang-undang Perlindungan Konsumen nomor 8 tahun 1999 menyatakan bahwa konsumen adalah setiap orang pemakai barang dan/atau jasa yang tersedia dalam masyarakat, baik bagi kepentingan diri sendiri, keluarga, orang lain maupun makhluk hidup lain dan tidak untuk diperdagangkan Hukum memberikan hak serta kewajiban kepada penumpang, untuk menggambarkan perlindungan hukum yang diberikan kepada penumpang selaku konsumen, dalam usaha untuk memenuhi kebutuhannya dari hal-hal yang dapat merugikan konsumen itu sendiri. Maka Mengenai hak dan kewajiban penumpang diatur dalam Pasal 4 dan 5 Undang-undang No. 8 Tahun 1999 tentang perlindungan konsumen menyatakan bahwa Seorang penumpang dalam perjanjian angkutan udara tentunya mempunyai hak untuk diangkut ke tempat tujuan dengan pesawat udara yang telah ditunjuk atau dimaksudkan dalam perjanjian angkutan udara yang bersangkutan. Di samping itu juga penumpang atau ahli warisnya berhak

untuk menuntut ganti rugi atas kerugian yang dideritanya sebagai akibat adany kecelakaan penerbangan atas pesawat udara yang bersangkutan. Selain itu hak-hak penumpang lainnya adalah menerima dokumen yang menyatakannya sebagai penumpang, mendapatkan pelayanan yang baik, memperoleh keamanan dan keselamatan selama dalam proses pengangkutan dan lain-lain. ${ }^{7}$

Dalam perjanjian angkutan udara, kewajiban utama penumpang adalah mematuhi seluruh aturan penerbangan. Oleh karena itu, untuk memperoleh haknya juga harus melaksanakan kewajiban yaitu :

1. membayar uang angkutan, kecuali ditentukan sebaliknya

2. mengindahkan petunjuk-petunjuk dari pengangkut udara atau dari pegawai-pegawainya yang berwenang untuk itu

3. menunjukan tiketnya kepada pegawai-pegawai pengakut udara setiap saat apabila diminta.

4. tunduk kepada peraturan-peraturan pengangkut udara mengenai syaratsyarat umum perjanjian angkutan muatan udara yang disetujuinya

6 Harahap, Rabiah Z. "Aspek Hukum Perlindungan terhadap Penumpang Bus dalam Mewujudkan Perlindungan Konsumen." DE LEGA LATA: Jurnal Ilmu Hukum 1, no. 1 (2017): 211-233.

7 Muhammad, Hasbi, and Rinitami Njatrijani Suradi. "Perlindungan Hukum Bagi Konsumen Pengguna Jasa Angkutan Umum Bus dalam Pengangkutan Orang Berdasarkan Undangundang Nomor 8 Tahun 1999 Tentang Perlindungan Konsumen dan Undang-undang Nomor 22 Tahun 2009 Tentang Lalu Lintas dan Angkutan Jalan." Diponegoro Law Journal 5, no. 2 (2016): 1-13. 
5. memberitahukan kepada pengangkut tentang barang - barang berbahaya atau terlarang yang dibawa naik sebagai bagasi tercatat atau sebagai bagasi tangan, termasuk pula barang-barang terlarang yang ada pada dirinya. ${ }^{8}$

Menurut Aflah Lubis hak dan kewajiban penumpang adalah: ${ }^{9}$

1. hak penumpang angkutan udara adalah :

a. mendapatkan pelayanan yang baik dalam membeli tiket atau karcis pesawat.

b. mendapatkan pelayanan yang baik selama perjalanan dalam penerbangan.

c. mendapatkan santunan dari pihak pengangkut apabila terjadi kecelakaan.

d. menuntut ganti kerugian apabila pihak pengangkut merugikan penumpang.

2. kewajiban penumpang angkutan udara adalah:

a. membeli tiket atau karcis pesawat .

b. mematuhi peraturan yang diperintahkan pihak pengangkut demi kelancaran bersama.

Berdasarkan uraian mengenai hak dan kewajiban penumpang, maka dapat disebutkan bahwa hubungan hukum antara Perusahaan Angkutan Penerbangan dengan penumpang adalah bersifat perjanjian berkala yaitu perjanjian dengan syarat dilakukan hanya untuk waktu tertentu dan perbuatan tertentu sesuai dengan hak dan kewajiban penumpang dan Perusahaan Angkutan Penerbangan.

\subsection{Penundaan Penerbangan dan Tanggung jawab Perusahaan Angkutan Penerbangan Terhadap Penumpang}

Secara harfiah keterlambatan berarti tidak tepat atau tidak sesuai dengan waktu yang telah ditetapkan, atau dapat juga diartikan kemunduran jadwal. Dikaitkan dengan kegiatan penerbangan, maka dapat dikemukakan bahwa keterlambatan penerbangan (delay) adalah suatu keadaan dimana penerbangan tidak sesuai dengan waktu keberangkatan pesawat dari Bandar udara menuju Bandar udara tujuan. Keterlambatan penerbangan tentunya akan menimbulkan konsekuensi bagi penumpang antara lain: akan terlambat tiba di tempat tujuan, harus menunggu hingga diberangkatkan. Keterlambatan penerbangan bersifat paradoksal dengan tujuan penerbangan yaitu cepat tiba ditujuan. Keterlambatan penerbangan sampai dengan saat ini masih menjadi persoalan dalam kegiatan penerbangan, masalah ini banyak mendapat perhatian dari berbagai pihak, persoalan ini sering dikeluhkan oleh konsumen. Padahal alasan utama konsumen menggunakan jasa penerbangan adalah karena ketepatan waktu tiba di tempat tujuan.

Keluhan-keluhan konsumen berkenaan dengan keterlambatan penerbangan ini banyak di jumpai dimedia massa baik cetak maupun elektonik. Dengan demikian, apabila masih ada perusahaan penerbangan yang mencantumkan klausula baku yang membatasi tanggung jawabnya maka hal tersebut bertentangan dan batal demi

8 Umboh, Trully Nikita. "PERLINDUNGAN HUKUM TERHADAP KONSUMEN PENGGUNA JASA PENERBANGAN ATAS KERUGIAN YANG TERJADI DALAM PENGANGKUTAN UDARA." LEX ET SOCIETATIS 7, no. 9 (2020). 62-70

9 Iqbal Lubis, 2016, "Ini Hak Penumpang Jika Penerbangan Terlambat", Serial Online Mei Juni , URL : https://m.Tempo.co/read/now/2016 , diakses tanggal 13 Agustus 2020. 
hukum(neitig). Dalam perkembangan penerbangan dalam negeri, para penumpang tidak banyak berbuat jika mengalami keterlambatan mereka hanya pasrah menerima saja apa yang diputuskan oleh maskapai penerbangan, menganggap hal yang wajar, perusahaan penerbangan selalu beralasan bahwa penundaan jadwal penerbangan dikarenakan alasan teknis pesawat demi keselamatan dan keamanan penerbangan. Dalam sejarah penerbangan di negeri ini tidak banyak perkara di pengadilan yang berkaitan dengan keterlambatan penerbangan. ${ }^{10}$

Dalam perjanjian pengangkutan terdapat hak dan kewajiban para pihak yang harus dilaksanakan dengan baik. Apabila penumpang tidak melaksanakan kewajibannya itu, maka sebagai konsekuensinya pengakut udara berhak untuk membatalkan perjanjian angkutan udara itu. Disamping itu juga apabila penumpang yang melalaikan kewajibannya itu kemudian menimbulkan kerugian sebagai akibat perbuatannya itu, maka sebagai penumpang harus bertanggung jawab atas kerugian tersebut.

Prinsip tanggung jawab merupakan perihal yang sangat penting dalam hukum perlindungan konsumen. Dalam kasus-kasus pelanggaran hak konsumen, diperlukan kehati-hatian dalam menganalisis siapa yang harus bertanggung jawab dan seberapa tangung jawab dapat dibebankan kepada pihak-pihak terkait.11 Secara umum, prinsipprinsip tanggung jawab dalam hukum penerbangan adalah sebagai berikut :

1. Prinsip tanggung jawab hukum berdasarkan kesalahan (Based on Fault Liability).

Tanggung jawab hukum atas dasar kesalahan terdapat dalam Pasal 1365 Kitab Undang-undang Hukum Perdata. Pasal tersebut yang dikenal sebagai tindakan melawan hukum (onrechtsmatigdaad) berlaku umum terhadap siapa pun juga, termasuk perusahaan penerbangan. Menurut pasal tersebut setiap perbuatan melawan hukum yang menimbulkan kerugian terhadap orang lain mewajibkan orang yang karena perbuatannya menimbulkan kerugian itu mengganti kerugian (to compensate the damage). Berdasarkan kententuan tersebut setiap orang harus bertanggung jawab secara hukum atas perbuatan sendiri artinya apabila orang karena perbuataanya mengakibatkan kerugian kepada orang lain, maka orang tersebut harus bertanggung jawab untuk membayar ganti kerugian yang diderita oleh orang tersebut.. Menurut Pasal 1367 Kitab Undang-undang Hukum Perdata, tanggung jawab hukum kepada orang yang menderita kerugian tidak hanya terbatas kepada perbuatan sendiri, melainkan juga perbuatan karyawan, pegawai, agen, perwakilannya apabila menimbulkan kerugian kepada orang lain, sepanjang orang tersebut bertindak sesuai dengan tugas dan kewajiban yang dibebankan kepada orang tersebut. Tanggung jawab atas dasar kesalahan harus memenuhi unsur ada kesalahan, ada kerugian, yang membuktikan adalah korban yang menderita kerugian, kedudukan tergugat dengan penggugat sama tinggi dalam arti saling dapat membuktikan, bilamana terbukti ada kesalahan maka jumlah ganti kerugian tidak terbatas. Apabila ada kesalahan, tetapi tidak mengakibatkan kerugian, maka perusahaan tidak akan bertanggung jawab, demikian pula ada

10 Sinilele, Ashar. "PERLINDUNGAN HUKUM TERHADAP PENUMPANG PADA TRANSPORTASI UDARA NIAGA PADA BANDARA SULTAN HASANUDDIN MAKASSAR." Al Daulah: Jurnal Hukum Pidana dan Ketatanegaraan 5, no. 2 (2016): 191-212.

11 Susanto, Happy, Hak-Hak Konsumen Jika Dirugikan, (Jakarta Selatan, Transmedia Pustaka, 2008), 23. 
kerugian tetapi tidak ada hubungannya dengan kesalahan pengangkutan, maka perusahaan juga tidak akan bertanggungjawab. ${ }^{12}$

2. Prinsip tanggung jawab praduga bersalah (Presumption of Liability).

Menurut konsep tanggung jawab hukum atas dasar praduga bersalah (presumption of liability), bahwa seorang pengangkut atau perusahaan penerbangan dianggap bertanggung jawab atas kerugian yang ditimbulkan pada penumpang dan/atau pengiriman barang tanpa dibuktikan kesalahan lebih dahulu, kecuali perusahaan penerbangan membuktikan tidak bersalah. Jadi penumpang dan/atau pengirim barang yang dirugikan tidak perlu membuktikan kesalahan perusahaan penerbangan, cukup memberi tahu adanya kerugian yang terjadi pada saat kecelakan. ${ }^{13}$

3. Prinsip tanggung jawab hukum tanpa bersalah (Presumption of Non Liability).

Prinsip ini dijumpai dalam Konvensi Warsawa dan Ordonansi Pengangkutan udara, meskipun tidak dengan tegas-tegas dinyatakan, dan berlaku untuk apa yang disebut "bagasi tangan", yaitu barang-barang yang di bawah pengawasan penumpang sendiri, sebagai istilah lawan dari "bagasi tercatat", yaitu bagasi yang oleh penumpang sebelum keberangkatan pesawat udara diserahkan kepada pengangkut untuk diangkut. Dalam Konvensi Warsawa dinyatakan bahwa mengenai barang-barang yang di bawah pengawasan sendiri, tidak tunduk pada konvensi, penumpanglah yang mengawasi dan menanggung risikonya. ${ }^{14}$

4. Prinsip tanggung jawab mutlak (Absolute Liability).

Menurut prinsip ini, pengangkut harus bertanggung jawab atas setiap kerugian yang timbul dalam pengangkutan yang diselenggarakannya tanpa keharusan pembuktian ada tidaknya kesalahan pengangkut. Prinsip ini tidak mengenal beban pembuktian dan unsur kesalahan dari tanggung jawab dengan alasan apapun yang menimbulkan kerugian itu. ${ }^{15}$

5. Prinsip tanggung jawab terbatas (Limitation of Liability).

Prinsip ini menguntungkan para pelaku usaha karena mencantukan klausula eksonerasi dalam perjanjian standar yang dibuatnya. Prinsip ini dilarang berdasarkan pasal 18 ayat 1 huruf a dan g Undang-undang Perlindungan Konsumen. Shidarta mengatakan bahwa : Prinsip tanggung jawab terbatas ini sangat merugikan konsumen bila ditetapkan secara sepihak oleh pelaku usaha. Dalam Undang-undang Perlindungan Konsumen yang baru, seharusnya pelaku

12 Setiawan, Rahmat. "TINJAUAN HUKUM TERHADAP PRINSIP TANGGUNG JAWAB (LIABILITY PRINCIPLE) ATAS KERUSAKAN BARANG DALAM ANGKUTAN MENURUT KONSEPSI UNDANG-UNDANG NOMOR 22 TAHUN 2009." Jurnal Yustisiabel 2, no. 2 (2018): 202-229.

13 K. Martono dan Agus Pramono, Hukum Udara Perdata Internasional dan Nasional, (Jakarta, Raja Grafindo Persada, 2013), 13.

14 Lede, Fransiskus Desales Jeri. "PERTANGGUNGJAWABAN ATAS KERUGIAN YANG TERJADI DALAM PENGANGKUTAN DI LAUT MENURUT UNDANG-UNDANG NO. 17 TAHUN 2008 TENTANG PELAYARAN." LEX ET SOCIETATIS 7, no. 2 (2019).

15 Nur, Yudha Hadian, and Dwi Wahyuniarti Prabowo. "Penerapan Prinsip Tanggung Jawab Mutlak (Strict Liability) dalam Rangka Perlindungan Konsumen." Buletin Ilmiah Litbang Perdagangan 5, no. 2 (2011): 177-195. 
usaha pelaku usaha tidak boleh secara sepihak menentukan klausula yang merugikan konsumen, termasuk membatasi maksimal tanggung jawab. Jika ada pembatasan mutlak harus berdasarkan pada peraturan perundang-undangan. ${ }^{16}$

Berdasarkan Undang-Undang No. 1 Tahun 2009 tentang Penerbangan, pada Pasal 146 dan 147 ditentukan bahwa apabila terjadi keterlambatan jadwal penerbangan, maka pihak perusahaan pengangkut udara wajib bertanggung jawab atas kerugian keterlambatan tersebut dan dalam Peraturan Menteri Nomor 77 Tahun 2011 tentang Tanggung Jawab Pengangkut Angkutan Udara pada pasal 10, yaitu:

1.keterlambatan lebih dari 4 (empat) jam diberikan ganti rugi sebesar Rp. 300.000,00 (tiga ratus ribu rupiah) per penumpang;

2.diberikan ganti kerugian sebesar 50\% (lima puluh persen) dari ketentuan huruf a apabila pengangkut menawarkan tempat tujuan lain yang terdekat dengan tujuan penerbangan akhir penumpang (re-routing), dan pengangkut wajib menyediakan tiket penerbangan lanjutan atau menyediakan transportasi lain sampai ke tempat tujuan apabila tidak ada moda transportasi selain angkutan udara;

Menurut Bapak I Made Bagus Gede Wijaya selaku penumpang pesawat Lion Mentari Airlines dalam hal terjadi keterlambatan hanya diberikan makanan dan minuman ringan, pelaksanaan tanggung jawab tersebut terhambat faktor pelayanan, kurangnya pelayanan yang baik dari pihak PT Lion Mentari Airlines dalam proses pemberian ganti rugi menyebabkan pelaksanaan tangggung jawab menjadi kurang efektif (wawancara tanggal 16 Agustus 2017).

Sedangkan menurut Ibu Lily Ramali bagian Operasional dan Tiketing PT. Lion Mentari Airlines (Cabang Bandara Ngurah Rai) dalam hal terjadi keterlambatan (delay) jika keterlambatan lebih dari 4 (empat) jam akan diberikan ganti kerugian sebesar Rp. $300.000,00$ (tiga ratus ribu rupiah) per orang penumpang, namun apabila keterlambatan hanya berlangsung 1 sampai 2 jam pihaknya akan memberikan berupa makanan dan minuman ringan. (wawancara tanggal 16 Agustus 2017).

Penulis juga melakukan penelitian dengan teknik wawancara di perusahaan angkutan penerbangan yang lain diantaranya perusahaan angkutan penerbangan PT. Garuda Indonesia dan PT. Citilink Indonesia, yakni dengan :

1. Bapak I Wayan Alit Semara selaku pihak Operasional dan Tiketing PT. Garuda Indonesia yang menyatakan bahwa apabila ada keterlambatan penerbangan yang terjadi maka PT. Garuda Indonesia bertanggung jawab mutlak terhadap setiap kerugian yang dialami penumpang., namun berbeda jika PT. Garuda Indonesia bisa membuktikan bahwa maskapai penerbangan tidak bersalah, maka PT. Garuda Indonesia dibebaskan dari tanggung jawab membayar ganti kerugian. Dengan begitu ,adanya bentuk tanggung jawab dari pihak PT. Garuda Indonesia akan lebih mampu menjaga ketepatan waktu serta memberikan perlindungan keamanan agar dapat meningkatkan kepercayaan dari masyarakat yang menggunakan angkutan udara tersebut.

2. Ibu Putu Cahyanie Dewi selaku pihak Operasional dan Tiketing PT. Citilink Indonesia yang merupakan anak perusahaan PT. Garuda Indonesia (Cabang Bandara Ngurah Rai) menyatakan bahwa bertanggung jawab mutlak

16 Imon, Linda L. "Prinsip Tanggung Jawab Dalam Pengangkutan Udara Menurut UndangUndang No. 1 Tahun 2009 Tentang Penerbangan." Journal Scientia De Lex 4, no. 3 (2016): $1-7$. 
terhadap setiap kerugian yang dialami penumpang dengan bentuk tanggung jawab adalah memberikan makanan dan minuman apabila keterlambatan terjadi dalam waktu 1 hingga 2 jam lamanya dan apabila lewat dari waktu tersebut pihak perusahaan akan me refund uang tiket penumpang dan menyarankan untuk menaiki maskapai penerbangan lainnya.

Wawancara ini dilakukan guna melakukan perbandingan terhadap obyek penelitian yang hanya ditekankan oleh penulis di PT. Lion Mentari Airlines dan hasil perbandingan tersebut adalah terjadinya kesamaan dalam bentuk tanggung jawab yang diberikan oleh perusahaan angkutan penerbangan dalam keterlambatan penerbangan dalam waktu 1 hingga 2 jam hanya diberikan makanan dan minuman berupa snack, dan perbedaannya adalah nilai nominal dalam bentuk ganti kerugian yaitu PT. Lion Mentari Airlines hanya memberikan uang ganti kerugian sebesar Rp. 300.000,00 (tiga ratus ribu rupiah) sedangkan PT. Citilink Indonesia dan PT. Garuda Indonesia memberikan uang ganti kerugian sesuai harga tiket yang penumpang bayarkan sebelumnya, dalam hal ini PT. Garuda Indonesia dan PT. Citilink Indonesia tidak menerapkan Peraturan Menteri Nomor 77 Tahun 2011 tentang Tanggung Jawab Pengangkut Angkutan Udara Pasal 10, yang mengatur keterlambatan lebih dari 4 (empat) jam hanya diberikan ganti rugi sebesar Rp. 300.000,00 (tiga ratus ribu rupiah) per penumpang, diberikan ganti kerugian sebesar $50 \%$ (lima puluh persen) dan apabila pengangkut menawarkan tempat tujuan lain yang terdekat dengan tujuan penerbangan akhir penumpang (re-routing) pengangkut wajib menyediakan tiket penerbangan lanjutan atau menyediakan transportasi lain sampai ke tempat tujuan apabila tidak ada moda transportasi selain angkutan udara, dalam hal dialihkan kepada penerbangan berikutnya atau penerbangan milik Badan Usaha Niaga Berjadwal lain, penumpang dibebaskan dari biaya tambahan, termasuk peningkatan kelas pelayanan (up grading class) atau apabila terjadi penurunan kelas atau sub kelas pelayanan, maka terhadap penumpang wajib diberikan sisa uang kelebihan dari tiket yang dibeli.

\section{Kesimpulan}

Hubungan hukum antara Perusahaan Angkutan Penerbangan khususnya PT. Lion Mentari Airlines dengan penumpang adalah hubungan hukum yang sifatnya perjanjian berkala yaitu perjanjian dengan syarat dilakukan hanya untuk waktu tertentu dan perbuatan tertentu. Tanggung jawab perusahaan angkutan penerbangan khususnya PT. Lion Mentari Airlines terhadap penumpang dalam hal terjadinya keterlambatan penerbangan, yaitu berdasarkan Undang-Undang No. 1 Tahun 2009 pada Pasal 146 dan 147 ditentukan bahwa apabila terjadi keterlambatan jadwal penerbangan, maka pihak perusahaan pengangkut udara wajib bertanggung jawab atas kerugian keterlambatan tersebut. Untuk rincian besarnya tanggung jawab dalam Peraturan Menteri Nomor 77 Tahun 2011 Pasal 10, yaitu keterlambatan lebih dari 4 (empat) jam diberikan ganti rugi sebesar Rp. 300.000,00 (tiga ratus ribu rupiah) per penumpang, diberikan ganti kerugian sebesar 50\% (lima puluh persen) dan apabila pengangkut menawarkan tempat tujuan lain yang terdekat dengan tujuan penerbangan akhir penumpang (re-routing) pengangkut wajib menyediakan tiket penerbangan lanjutan atau menyediakan transportasi lain sampai ke tempat tujuan apabila tidak ada moda transportasi selain angkutan udara, dalam hal dialihkan kepada penerbangan berikutnya atau penerbangan milik Badan Usaha Niaga Berjadwal lain, penumpang dibebaskan dari biaya tambahan, termasuk peningkatan 
kelas pelayanan (up grading class) atau apabila terjadi penurunan kelas atau sub kelas pelayanan, maka terhadap penumpang wajib diberikan sisa uang kelebihan dari tiket yang dibeli.

\section{DAFTAR PUSTAKA}

Buku:

Marzuki, Peter Mahmud, Penelitian Hukum, (Jakarta, Prenada Media Group, 2008), 93.

Susanto, Happy, Hak-Hak Konsumen Jika Dirugikan, (Jakarta Selatan, Transmedia Pustaka, 2008), 23.

\section{Jurnal:}

Amalia, Laili Rizki. "Perlindungan Hukum Konsumen Jasa Akibat Pembatalan Keberangkatan Jamaah Umroh Berdasarkan Undang-undang Perlindungan Konsumen." PhD diss., UNIVERSITAS 17 AGUSTUS 1945, 2018.

Harahap, Rabiah Z. "Aspek Hukum Perlindungan terhadap Penumpang Bus dalam Mewujudkan Perlindungan Konsumen." DE LEGA LATA: Jurnal Ilmu Hukum 1, no. 1 (2017): 211-233.

Imon, Linda L. "Prinsip Tanggung Jawab Dalam Pengangkutan Udara Menurut Undang-Undang No. 1 Tahun 2009 Tentang Penerbangan." Journal Scientia De Lex 4, no. 3 (2016):1-7.

K. Martono dan Agus Pramono, Hukum Udara Perdata Internasional dan Nasional, (Jakarta, Raja Grafindo Persada, 2013), 13.

Lede, Fransiskus Desales Jeri. "PERTANGGUNGJAWABAN ATAS KERUGIAN YANG TERJADI DALAM PENGANGKUTAN DI LAUT MENURUT UNDANGUNDANG NO. 17 TAHUN 2008 TENTANG PELAYARAN." LEX ET SOCIETATIS 7, no. 2 (2019).

MAIZANI, SITI ADLIAH, Annalisa Yahanan, and Arfianna Novera. "TANGGUNG JAWAB PT. LION AIR ATAS KEHILANGAN BAGASI TERCATAT PENUMPANG (Studi Putusan Mahkamah Agung Nomor 2985 K/Pdt/2013)." PhD diss., Sriwijaya University, 2018.

Muhammad, Hasbi, and Rinitami Njatrijani Suradi. "Perlindungan Hukum Bagi Konsumen Pengguna Jasa Angkutan Umum Bus dalam Pengangkutan Orang Berdasarkan Undang-undang Nomor 8 Tahun 1999 Tentang Perlindungan Konsumen dan Undang-undang Nomor 22 Tahun 2009 Tentang Lalu Lintas dan Angkutan Jalan." Diponegoro Law Journal 5, no. 2 (2016): 1-13.

Nur, Yudha Hadian, and Dwi Wahyuniarti Prabowo. "Penerapan Prinsip Tanggung Jawab Mutlak (Strict Liability) dalam Rangka Perlindungan Konsumen." Buletin Ilmiah Litbang Perdagangan 5, no. 2 (2011): 177-195.

Prajogo, Abimanyu Faiz, and H. K. Martono. "TANGGUNG JAWAB PENGANGKUT TERHADAP PENUMPANG YANG TIDAK TERDAFTAR DALAM MANIFES (STUDI KASUS JATUHNYA PESAWAT LION AIR JT 610 DI KARAWANG)." Jurnal Hukum Adigama 2, no. 2 (2019). 1-19.

Setiawan, Rahmat. "TINJAUAN HUKUM TERHADAP PRINSIP TANGGUNG JAWAB (LIABILITY PRINCIPLE) ATAS KERUSAKAN BARANG DALAM ANGKUTAN MENURUT KONSEPSI UNDANG-UNDANG NOMOR 22 TAHUN 2009." Jurnal Yustisiabel 2, no. 2 (2018): 202-229.

Sinilele, Ashar. "PERLINDUNGAN HUKUM TERHADAP PENUMPANG PADA TRANSPORTASI UDARA NIAGA PADA BANDARA SULTAN HASANUDDIN 
MAKASSAR." Al Daulah: Jurnal Hukum Pidana dan Ketatanegaraan 5, no. 2 (2016): 191-212.

Umboh, Trully Nikita. "PERLINDUNGAN HUKUM TERHADAP KONSUMEN PENGGUNA JASA PENERBANGAN ATAS KERUGIAN YANG TERJADI DALAM PENGANGKUTAN UDARA." LEX ET SOCIETATIS 7, no. 9 (2020). 6270.

Wiradipradja, E. Saefullah. "Tanggung Jawab Perusahaan Penerbangan Terhadap Penumpang Menurut Hukum Udara Indonesia." Jurnal Hukum Bisnis 25, no. 1 (2006), 5 .

\section{Internet:}

Iqbal Lubis, 2016, "Ini Hak Penumpang Jika Penerbangan Terlambat", Serial Online Mei - Juni , URL : https://m.Tempo.co/read/now/2016, diakses tanggal 13 Agustus 2020.

\section{Peraturan Perundang-Undangan:}

Kitab Undang-Undang Hukum Perdata, (Burgerlijk Wetboek), Tahun 1838, diterjemahkan oleh R. Subekti dan R. Tjitro Sudibio, penerbit Balai Pustaka

Indonesia, Undang-Undang Dasar Tahun 1945, Lembaran Negara Republik Indonesia Tahun 1946 Nomor 7, Tambahan Lembaran Negara Republik Indonesia Tahun 1959 Nomor 75 dan Berita Negara Tahun 1959, Nomor 69.

Indonesia, Undang-Undang tentang Perlindungan Konsumen, Undang-Undang Nomor 8 Tahun 1999, Lembaran Negara Republik Indonesia Nomor 42 Tahun 1999, Tambahan Lembaran Negara Republik Indonesia Nomor 3821.

Indonesia, Undang-Undang tentang Penerbangan, Undang-Undang Nomor 1 Tahun 2009, Lembaran Negara Republik Indonesia Nomor 1 Tahun 2009, Tambahan Lembaran Negara Republik Indonesia Nomor 4956.

Indonesia, Peraturan Pemerintah Republik Indonesia tentang Pembinaan Pengawasan dan penyelenggaraan Perlindungan Konsumen, Peraturan Pemerintah Nomor 58 Tahun 2001, Lembaran Negara Republik Indonesia Nomor 103 Tahun 2001, Tambahan Lembaran Negara Republik Indonesia Nomor 4126. 